\title{
TELAAH KRITIS METODE HISAB PENENTUAN AWAL RAMADHAN PENGIKUT HABIB SEUNAGAN NAGAN RAYA-ACEH.
}

\author{
Ismail \\ IAIN Lhokseumawe \\ ismail@iainlhokseumawe.ac.id \\ Rasyidin \\ IAIN Langsa \\ rasyidin83iainlangsa@gmail.com
}

\begin{abstract}
This journal explains about the Habib Seunagan followers' calculation method of the beginning of Ramadan's determination and normative review of the practice of determining the beginning of Ramadan which has been used to date. The result of the research can be explained that Habib Seunagan's followers use hisab 'urfi khumasi (not hisab hakiki taqribi) that has been modified from the original method by adding abstinence day before the beginning of Ramadan fasting on Wednesday and Friday to begin Ramadan fasting. Normatively, after considering the legal basis from Alquran, Hadist, and fatwa ulama about the beginning of Ramadan's determination, then the Habib Seunagan followers' practice of determining the beginning of Ramadan based on hisab 'urfi khumasi is not in accordance with the provisions of the law, considering that when starting Ramadan fasting, the essence is still on the $28^{\text {th }}$ or the $29^{\text {th }}$ of Sya'ban based on hisab hakiki tarqibi and can be proven by the sight of the old crescent in the eastern horizon before sunrise on the first day of the Habib Seunagan followers' Ramadan fasting.
\end{abstract}

Keywords: astronomy, hisab 'urfi khumasi, ramadan fasting, nagan raya. 
Abstrak: Tulisan ini menjelaskan tentang metode hisab penentuan awal Ramadhan pengikut Habib Seunagan dan tinjauan normatif terhadap praktik penentuan awal Ramadhan yang selama ini digunakan. Hasil penelitian dapat dijelaskan bahwa pengikut Habib Seunagan dalam mengawali puasa Ramadhan menggunakan hisab 'urfi khumasi (bukan hisab hakiki taqribi) yang telah dimodifikasi dari metode asalnya dengan menambahkan hari pantangan mengawali puasa Ramadhan pada hari Rabu dan Jumat. Secara normatif, setelah menimbang landasan hukum dari Alquran, Hadist, dan fatwa ulama tentang penetapan awal puasa Ramadhan, maka praktik penentuan awal puasa Ramadhan pengikut habib Seunagan yang berpedoman pada hisab 'urfi khumasi tidak sesuai dengan ketentuan hukum, mengingat saat mengawali puasa Ramadhan, hakekatnya masih tanggal 28 atau 29 bulan Sya'ban secara hisab hakiki tarqibi dan bisa dibuktikan dengan masih terlihatnya bulan sabit tua di ufuk timur sebelum matahari terbit pada hari pertama pengikut Habib Seunagan berpuasa Ramadhan.

Kata Kunci: ilmu falak, hisab 'urfi khumasi, puasa ramadhan, nagan raya.

\section{PENDAHULUAN.}

Di Indonesia, hampir bisa dikatakan ada sebuah "kesepakatan untuk berbeda" dalam mengawali dan mengakhiri bulanRamadhan. Hal ini bisa dilihat secara nyata sampai Ramadhan saat ini $(1440 \mathrm{H})$ belum ada keseragaman dalam mengawali dan mengakhiri berpuasa di Indonesia. Wacana otoritas tunggal hanya sebuah wacana, sudah lama diwacanakan dan diusahakan agar pemerintah melalui sidang itsbat mampu menjadi otoritas tunggal dalam penentuan awal dan akhir Ramadhan di Indonesia. Upaya dan usaha ini sekilas bisa dikatakan gagal, mengingat hampir semua ormas Islam di Indonesia menjadikan dan memilih kriteria penentuan awal bulan hijriah yang berbeda sebagai simbol organisasi atau sebagai identitas dalam perpolitikan di Indonesia. 
Banyak yang telah menganalisa terhadap perbedaan dalam penetapam awal dan akhir Ramadhan di Indonesia. Seperti Ahmad Wahidi, menurutnya ada tiga faktor penyebab terjadinya perbedaan. Pertama, adanya perbedaan pemahaman dalam menafsirkan dalil perintah mengawali dan mengakhiri puasa antara rukyat dan hisab. Kedua, adanya perbedaan pada sistem dan metode perhitungan antara hisab hakiki dengan hisab 'urfi. Ketiga, adanya perbedaan dalam memilih kriteria penentuan awal bulan hijriah antara kriteria ljmak, rukyat dan imkan rukyat (Ahmad Wahidi, 2012). Ahmad Musonnif juga menjelaskan penyebab perbedaan penentuan awal dan akhir Ramadhan di Indonesia. Menurutnya, pemahaman tipologi epistimologi hukum Islam para tokoh agama ikut andil dalam mewarnai perbedaan awal bulan hijriah di Indonesia, sebagaimana dicontohkan pada tokoh agama di Tulungagung. Mereka ada yang menganut tipologi normatif (bayani), tipologi rasional (burhani) dan tipologi intuituif (irfani) (Musonif, 2019). Ada juga yang telah menawarkan solusi terhadap perbedaan tersebut, diantaranya Wanti Marpaung, menurut nya "mazhab negara" adalah solusi dalam perbedaan penetapan awal dan akhir Ramadhan di indonesia. Mazhab negara adalah peran negara dalam melegalisasi aturan dalam penetapan awal bulan hijriah, mulai dari kriteria, metode dan hasil yang bisa dipaksakan untuk seluruh Indonesia (Marpaung, 2018). Nurul Badriyah dan Faisal menwarkan solusi dengan menjadikan konseb ittihadul mathla' sebagai solusi terhadap perbedaan awal dan akhir puasa yang terjadi selama ini di Indonesia. Ittihadul mathla' adalah menjadikan wilayah Kesatuan Republik Indonesia (NKRI) sebagai satu matlak hilal dalam penentuan awal bulan hijriah di Indonesia, artinya bila salah satu tempat rukyah hilal di Indonesia berhasil mengamati hilal, maka kesaksian hilal di tempat tersebut bisa berlaku untuk seluruh wilayah Indonesia (Badriyah, 2018). Dari semua persmasalahan yang telah ada dan tawaran solusi yang telah dikembangkan oleh para akademisi, namun langkah untuk keseragaman dalam mengawali dan mengakhiri puasa di Indonesia masih dalam katagori wacana, belum mampu sampai pada tahap aplikasi. 
Tulisan ini bukan bahagian dari memberi solusi atau memetakan faktor terjadinya perbedaan dalam mengawali dan mengakhiri puasa yang selama ini selalu terjadi perbedaan di Indonesia. Namun, tulisan ini hanya mendeskripsikan tentang metote hisab yang digunakan oleh pengikut Habib Seunagan dalam menentukan awal Ramadhan dan bagaimana status hukum bagi pengikut Habib Seunagan dalam mengamalkan dengan metode hisab untuk penetuan awal dan akhir Ramadhan. Tulisan ini merupakan lanjutan dari penelitian penulis yang pernah ada dengan judul Melacak metode penentuan awal bulan hijriah pengikut Abu Peuleukung Nagan Raya (Ismail, 2018). Hasil penelitian menjelaskan bahwa pengikut Habib Seunagan menggunakan metode hisab 'urfi khumasi dalam menetukan awal bulan Ramadhan. Selain penulis, ada juga yang meneliti tentang metode hisab pengikut Habib Seunagan, seperti Asih Pertiwi dengan judul Metode penentuan awal akhir Ramadhan menurut tarekat Syattariah di desa Peuleukung Kecamatan Seunagan Timur Kabupaten Nagan Raya Aceh (Pertiwi, 2017). Hasil penelitian menjelaskan bahwa pengikut Habib Seunagan menggunakan metode hisab khumasi dalam menetapkan awal dan akhir Ramadhan dengan menambahkan pantangan mengawali puasa bila jatuh pada hari Rabu atau Jumat.

Cut Rahma Rizky juga pernah membuat penelitian tentang metode penentuan awal Ramadhan pengikut Habib Seunagan dengan judul Patronase masyarakat peuleukung (Nagan Raya) pengikut Abu Habib Seunagan dalam menentukan 1 Ramadhan (Rizky, UIN Walisongo). Hasil penelitian ini juga menjelaskan bahwa pengikut Habib Seunagan menggunakan hisab urfi dalam menentukan masuk 1 Ramadhan dengan cara musyawarah dan diputuskan dalam rapat yang diadakan setiap tanggal 15 Syakban. Terakhir penulis menemukan penelitian yang dilakukan oleh Nur Aini dengan judul Perbandingan sistem penentuan awal bulan kamariah tarekat Syattariah Peuleukung Aceh dan tarekat Syattariah Ulakan Padang (Nuraini, 2018). Hasil penelitian ini juga menjelaskan pengikut habib Seunagan menggunkan metode hisab urfi yang hanya dialamatkan kepada kitab Tajul Muluk, walau sebenarnya metode tersebut tidak ada dalam 
kitab tajul muluk. Informasi terahir penulis terima dari penjelasan juru bicara Habib Muda Seunagan, T M. Marsyur Alam pada Serambi On TV. Beliau menjelaskan bahwa selama ini pengikut Habib Muda Seunagan dalam menentukan awal bulan Ramadhan menggunakan hisab hakiki taqribi (https://www.youtube.com/watch, 2019).

Dari semua penelitian sebelumnya, belum ada yang merumuskan secara jelas metode hisab penentuan awal Ramadhan pengikut Habib Seunagan dan belum ada yang melihat dari sisi normatif terhadap praktik penentuan awal Ramadhan pengikut Habib Seunagan. Penelitian ini mencoba mendeskripsikan model metode penentuan awal Ramadhan pengikut Habib Seunagan dan analisa hukum terhadap pedoman dalam mengawali puasa Ramadhan. Tulisan ini termasuk dalam jenis kualitatif dengan pendeka normatif mencoba untuk menjelaskan metode hisab penetuan awal Ramadhan dan mengkaji secara kritis terhadap hukum mengawali puasa dengan metode hisab yang sekarang digunakan oleh pengikut Habib Seunagan Nagan Raya-Aceh.

\section{KLASIFIKASI SISTEM HISAB DI INDONESIA}

Sistem hisab penentuan awal bulan qamariyah yang berkembang di Indonesia sangat beragam dengan rujukan yang juga ikut beragam, hal ini seiring dengan perkembangan ilmu falak itu sendiri, mulai dari sistem hisab 'urfi, hisab hakiki taqribi, hisab hakiki tahkiki dan hisab hakiki kontemporer. Klasifikasi ini dimunculkan dan disepakati dalam keputusan temu kerja evaluasi hisab rukyat tahun 2006 di hotel Ria Diani, Bogor, Jawa Barat, mulai tanggal 1-3 Juni 2006 (Siti Tatmainul Qulub, 2015).

Sejarah hisab urfi, penggalan islam sudah dimulai sejak kekhalifahan Umar bin khattab, tepatnya sejak terjadinya kebingungan umat islam terhadap sebuah dokumen penting tertulis bulan syakban, akan tetapi karena belum memiliki system penggalan, menimbulkn pertanyaan atas kebingunagan bagi Umar bib Khattab (Bashori, 2014). Hisab secra etimologi, kata hisab dari bahasa arab al- 
hasab yang berate al-adad wa al-ihsab.bilangan atau hitungan. Kalau di hubungkan dengan al-nasab keturunan, hisab berate menghitung keberanian, kemuliyaan, dan kebaikan nenek moyangnya. Dalam hadis rasulullah SWT. Mengatakan, wanita itu dinikah dalam empat hal, pertama maliha (hartanya), jamaliha (kecantikannya), hasdabiha, (keturunannya, dan diniha, (agamanya) lihat (HR.bukhari Muslim) (Moh. Murtadho, 2008). Hisab juga berate al-katsir banyak dan al-kafa, cukup seperti dalam al-Quran menjelaskan terdapat ungkapan 'atha'an hisaban yang berate 'atha'an katsiran kafityan, pembagian yang banyak yang mencukupi.

Adapun hisab menurut terminology, sering di hubungkan dengan ilmu hitung (arithmetic), yaitu suatu ilmu pengetahuan yang membahas tentang seluk beluk perhitungan. Sementara dalam literature klasik, ilmu hisab di samakan dengan ilmu falak, suatu ilmu yang mempeljari benda-benda langit, matahari, bulan, bintang,-bintang dan planet-planetnya semuanya yang ada di langit (Moh. Mortadho, 2008). Istilah hisab di kaitkan dengan system penentun awal bulan Qamariah berati suatu sistem penentuan awal bulan Qamariah yang didasarkan dengan perhitungan benda-benda langit, matahari dan bulan. Dengan kata lain, hisab adalah sistem perhitungn awal bulan Qamariah yang berdasarkan pada perjalanan (peredaran) bulan mengelilingi bumi.

Dengan sitemini, kita dapat memperkirakan dan menetapkan awal bulan jauh-jauh sebelumnya, sebab tidak tergantung pada terlihatnya hilal pada saat mata hari terbenam menjelang masuk tanggal 1 bulan Qamariah (Murtadho, 2008).

\section{Hisab 'urfi}

Hisab 'urfi adalah sistem perhitungan kalender hijriah berdasarkan pada peredaran rata-rata bulan selama setahun dalam mengelilingi bumi dan ditetapkan jumlah hari dalam setiap bulan secara konvesional, 30 hari untuk bulan ganjil dan 29 hari untuk bulan genap (Susiknan Azhari, 2008). Sistem hisab 'urfi 
diperkenalkan pada masa khalifah Umar bin Kattab Ra. pada tahun ke 17 hijriah untuk keperluan pencatatan administrasi negara waktu itu. Secara perhitungan, hisab 'urfi didasarkan pada perjalan bulan mengelilingi bumi dari ijtimak ke ijtimak berikutnya yang dikenal dengan periode sinodis dengan jumlah waktu yang dibutuhkan oleh bulan dalam satu kali putaran penuh adalah 29 hari 12 jam 2,8 detik (Slamet Hambali, 2013).

Dalam pendistribusian jumlah hari dalam setiap bulan dibuat berselangseling antara 30 dan 29 hari, untuk urutan bulan ganjil seprti Muharram, Rabiul awal ditetapkan 30 hari dan bulan genap seperti Safar, Rabiul Akhir ditetapkan 29 hari, perbedaan dalam penetapan jumlah hari dalam setiap bulan ini guna terakomodir sisi waktu dalam setiap bulan 12 jam. Untuk terakomodir sisa waktu setiap bulan 2,8 detik dibuatlah tahun kabisat dan tahun basitat dalam satu siklus 30 tahun. Dalam setiap 30 tahun ada 11 tahun kabisat (panjang) dengan jumlah 355 hari untuk satu tahun, yaitu tahun 2, 5, 7, 10, 13, 16, 18, 21, 24, 26, 29 dan 19 tahun basitat (pendek) dengan jumlah 354 hari untuk satu tahun dengan dijadikan umur bulan Zulhijjah 29 hari. Cara mengetahui tahun kabisat dan tahun basitat adalah dengan cara tahun dibagi 30 , bila sisanya seperti salah satu angka di atas, maka tahun itu tahun kabisat. Contoh tahun $1431 \mathrm{H}$ dibagi 30 bernilai 47 dan sisa 21. Karena sisa 21, maka tahun 1431 adalah tahun kabisat dengan jumlah hari bulan Zulhijjah 30 hari dan jumlah hari dalam setahun 355 hari (Anugraha, 2012).

Ada beberapa ciri yang membedakan antara hisab 'urfi dengan hisab hakiki. Pertama, jumlah hari dalam setahun ditentukan dengan sistem kabisat atau basitat, sedangkan hisab hakiki ditentukan oleh kondisi hilal dalam setiap bulan dalam setahun atau sistem sinodik. Kedua, jumlah hari dalam setiap bulan sudah pasti disetiap tahun nya dan selalu tersusun dengan selang-seling, untuk yang ganjil seperti Muharram, Rabiul Awal, Jumadil Awal, Rajab, Ramadhan, Zulkaidah selalu berumur 30 hari, untuk bulan genap seperti Safat, Rabiul Akhir, Jumadil Akhir, Syakban, Syawal dan Zulhijjah selalu berumur 29 hari, sedangkan umur bulan dalam hisab hakiki tidak tetap dan tidak teratur, tergantung kondisi hilal di 
setiap awal bulan, boleh jadi tahun ini jumlah hari pada bulan Ramadhan 30 hari, untuk tahun depan belum tentu juga 30 hari, boleh jadi 29 hari dan boleh juga terjadi berurutan 2 bulan berumur 30 hari atau sebaliknya. Ketiga, semua sistem hisab 'urfi ada siklus sebagai batas pengulangan dalam sistem perhitungan, ada yang menggunakan 30 tahun dalam satu siklus dan ada juga 8 tahun, sedangkan dalam hisab hakiki tidak dikenal dengan siklus, karena secara perhitungan tidak ada sisa waktu dalam setiap tahun yang membutuhkan kepada penyempurnaan di tahun-tahun berikutnya.

Di Indonesia, ada banyak sistem hisab 'urfi yang masih berkembang, seperti hisab 'urfi Umar bin Khattab, hisab 'urfi Asapon, hisab 'urfi Aboge, hisab 'urfi golek limo dan hiasab 'urfi khumasi. Contoh hisab 'urfi yang dikembangkan pada Umar bin Kattab adalah sebagai berikut:

Kapan jatuh 1 Ramadhan $1440 \mathrm{H}$ ?

$$
\begin{aligned}
\mathrm{JHH} & =\quad \mathrm{INT}((1440-1) \times 354,367)+236+1=510171,113 \\
\text { Jadi JHH } & \text { adalah } 510171 . \\
\mathrm{NH} & =\quad 510171 / 7=72881 \times 7=510167 \\
& =\quad 510171-510167=4 \text { (Minggu) } \\
\mathrm{JHM} & =\quad \mathrm{JHH}+227015 \\
& =510171+227015=737186 \\
\mathrm{JHM} & =737186 \\
\mathrm{TM} & =\mathrm{INT}(\mathrm{JHH} / 354,367)+1 \\
& =\quad \mathrm{NTT}(737186 / 365,25)=2018+1=2019 \\
\mathrm{TM} & =2019 \\
\mathrm{XM} & =(\mathrm{JHM}-\mathrm{INT}((\mathrm{TM}-1) \times 365,25))+\mathrm{AG} \\
& =((2019-1) \times 365,25)=737074 \\
& =737186-737074=112+13=125-120=5
\end{aligned}
$$

Jadi 1 Ramadhan $1440 \mathrm{H}$ adalah hari Minggu 5 Mei 2019 M.

Keterangan:

$\mathrm{JHM}=$ Jumlah hari masehi.

$\mathrm{JHH}=$ Jumlah hari hijriah

TM = Tahun masehi. 
$\mathrm{XM}=$ Jumlah hari dalam tahun masehi yang dikehendaki, sampai dengan tanggal yang dimaksud, dan ditambah 1 hari pada tiap-tiap tahun panjang (kabisah), sejak tanggal 1 Maret samapai dengan 31 Desember.

$\mathrm{XH} \quad=$ Jumlah hari dalam tahun hijriah yang dimaksud sampai dengan tanggal yang dicari dalam bulan yang dikehendaki.

AG = 10 hari, ditambah 1 (satu) hari untuk tiap-tiap abad yang tidak habis dibagi dengan 400 sejak tanggal 15 Oktober 1582. (sekarang sudah mencapai 13).

$\mathrm{NH}=$ Nama hari. (Isa, 2016)

Untuk daerah Aceh pada awal Abad ke 19 M terdapat sebuah tokoh ilmu falak yaitu Abbas bin Muhammad atau sering disebut dengan Syekh Abbas Kutakarang. (Hasna Tuddar Putri, 2013) Hisab 'urfi yang dikembangkan oleh Syekh Abbas Kutakarang layak dikupas mengingan ada kaitannya dengan persoalan penentuan awal Ramadhan pengikut Habib Seunagan di Nagan Raya-Aceh, dimana dalam sebuah laporan penelitian menjelaskan bahwa metode hisab pengikut Habib Seunagan merujuk pada kitab tajul muluk, dimana pada awal kitab ini membahas tentang hisab 'urfi Syekh Abbas Kutakarang. Contoh perhitungan hisab 'urfi dalam kitab Syekh Abbas Kutakarang untuk awal Ramadhan dan Syawal $1440 \mathrm{H}$.

$$
\begin{array}{ll}
1439-900=539 & \\
539 / 30=17 & \\
17 \times 30=510 & 17 \times 29=493 \\
539-510=29 & 11 \times 5=55 \\
& 18 \times 4=72 \\
& 55+72=127 \\
493+127=620 & \\
620+1=621 & \\
621 / 7=88 &
\end{array}
$$




$$
88 \times 7=616
$$

$$
621-616=5 \text { (ج) (Jumat) }
$$

Jadi 1 Muharram 1440 jatuh pada hari Jumat, untuk 1 Ramadhan $1440 \mathrm{H}$ jatuh pada hari Rabu dan 1 Syawal jatuh pada hari Sabtu. Pengikut Habib Seunagan mengawali puasa Ramadhan pada hari Sabtu 4 Mei 2019 dan berlebaran pada hari Senin 3 Juni 2019 (https://rencongpost.com, 2019).

\section{Hisab hakiki taqribi}

Hisab hakiki adalah sistem perhitungan posisi benda-benda langit berdasar gerak yang sebenarnya dan memperhatikan hal-hal yang berkaitan dengan perhitungan nya. Dalam praktik hisab awal bulan hijriah ada dikenal hisab hakiki taqribi, hisab hakiki tahkiki dan hisab hakiki kontemporer (Khzin, 2005). Hisab hakiki taqribi merupakan sebuah sistem perhitungan awal bulan qamriyah yang hasilnya mendekati kebenaran, hal ini dikarenakan sistem perhitungan yang masih sangat sederhana dan mampu diselesaikan tanpa alat bantu seperti kalkulator. Sistem perhitungan hisab hakiki taqribi kebanyakan hanya menggunakan penambahan, pengurangan dan perkalian yang sangat sederhana, belum menggunakan rumusrumus trigonometri bola.

Kitab ilmu falak yang masih menggunakan sistem hisab hakiki taqribi diantaranya adalah kitab Sulam al-naiyyirain karya K.H. Manshur al-Battawiy, kitab Fathur-Rauf al-mannan, dan kitab al-Khulasah al-Wafiyah. Dalam sistem hisab hakiki taqribi untuk menetukan awal bulan hijriah hanya mencari kapan terjadi ijtima' atau konjungsi, apabila konjungsi terjadi sebelum matahari terbenam, tinggi hilal selalu posistif atau di atas ufuk, hal ini dikarenakan cara untuk mendapatkan tinggi hilal hanya dengan rumus waktu terbenam matahari dikurangi waktu konjungsi, hasilnya dibagi dua, kemudian dikalikan satu derajat untuk mendapatkan ketinggian hilal dalam nilai derajat. 
Dari uraian di atas dapat disimpulkan bahawa ciri-ciri sistem hisab hakiki taqribi dalam penetuan awal bulan hijriah, diantaranya tidak menggunakan rumus trigonometri bola, tidak menghitung data bulan dan data matahari, tidak membutuhkan data koordinat lokasi dan data ketinggian tempat, sistem penyelesaian rumus hanya menggunakan penambahan, pengurangan dan perkalian yang sangat sederhana.

\section{Hisab haqiqi tahqiqi}

Sistem hisab haqiqi tahqiqi merupakan perkembangan dari sistem hisab hakiki taqribi, dimana dalam penentuan awal bulan hijriah telah menggunakan data koordinat lokasi, data ketinggian tempat, data matahari dan data bulan untuk menghitung ketinggian bulan, sudah menggunakan rumus trigonometri bola dan untuk penyelesaian rumus harus menggunakan alat seperti kalkulator atau komputer. Namun data matahari, data bulan dan data lainnya masih digunakan dalam bentuk tabel yang bersifat nilai rata-rata dan abadi, tidak diperbaharui dalam setiap tahun (Muchtar Yusuf, 2010). Diantara kitab ilmu falak yang menggunakan sistem hisab hakiki tahqiqi adalah Menara Kudus, Nur Anwar, alManahij al-Hamidiyyah, al-Khulasah al-Wafiyah, Badi'at al-Mithal dan Hisab Haqiqi (Qulub, 2019). Menurut K.H. Ma'shum Jombang, hisab haqiqi tahqiqi di cangkok dari kitab al-Matha al-Said Rushd al-Jadid yang berasal dari sistem hisab astronomi-astronomi Muslim tempo dulu dan telah dikembangkan oleh astronomi-astronomi modern (Barat) berdasarkan penelitian baru. Inti dari sistem ini adalah menghitung atau menentukan posisi matahari, bulan, dan titik simpul orbit bulan dengan orbit matahari dalam sistem koordinat ekliptika. Artinya, sistem ini mempergunakan table-tabel yang sudah dikoreksi dan perhitungan yang relative lebih rumit dari pada kelompok hisab haqiqi taqribi serta memakai ilmu ukur segitiga bola. 130 termasuk dalam kelompok ini, seprti kitab Khulashah al-Wafiyah (Bashori M. H., Pengantar Ilmu Falak, 2015). 


\section{Hisab Haqiqi Tadqiqi}

Sistem hisab ini selalu menggunakan perhitungn yang didasarkan pada data-data astronomi canggih dan modern. System haqiqi tadqiqi yang disintesakan dengan ilmu astronomi modern. Hal ini dilakukan dengan memperluas dan menambahkan koreksi dilakukan dengan memperluas dan menambahkan koreksi-koreksi gerak bulan dan matahari denga rumus-rumus spherical trigonomentri, sehingga didapat data yang sangat teliti dan akurat ( Sa'daduddin Djambak, 1976: 24-31). Di dalam menyelasaikan perhitungan digunakan alat-alat elektronika modern, misalnya kalkulator, computer dan alat-alat pendeteksi koordinat Lintang dan bujur dengan standart baik nasional maupun internasional, yaitu Gio Positioning System (GPS). Hisab dapat lebih akurat memperhitungkan posisi hilal sehingga pelaksanaan rukyt dapat dilakukan dengan lebih teliti. Termasuk system hisab ini antara lain Newcomb, Jean meuus, Almanac Nautika, dan the American Ephemiris (Moh. Murtahho, 2008). Dasar hukum sistem hisab yang telah di jelaskan beberapa point di atas adalah: dalam alQuran surat al-Baqarah ayat 189.

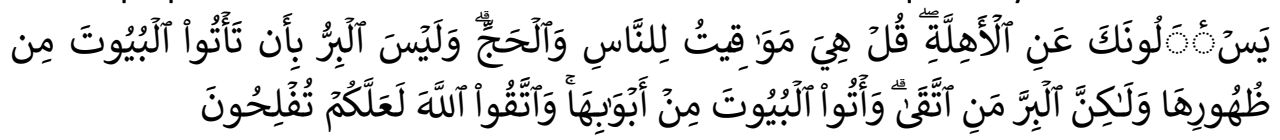

"Mereka bertanya Kepadamu Tentang bulan sabit (hilal). Katakanlah Bulan sabit itu adalah Tanda-tanda waktu bagi manusia dan (bagi ibadah) haji"

Petunjuk kedua adalah, Allah SWT menegaskan bahwa Allah SWT telah menetapkan manzilah-manzilah bagi peredaran bulan dengan tujuan agar kaum muslimin dapat mengetahui bilangan tahun dan perhitungan waktunya: Allah SWT menjelaskan dalam surah Yunus ayat 5 yang berbunyi,

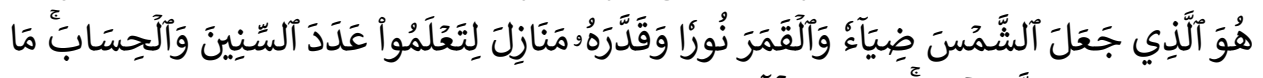

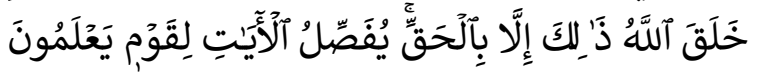


"Dialah yanmg menjadikan matahari bersinar dan bulan bercahaya dan ditetapkan manzilah-manzilah bagi perjalananbulan itu, supaya kami mengetahui bilangan tahun dan perhitungan waktu, Allah tidak menciptakan yang demikian itu melainkan dengfan dengan hak, dia menjelaskan tanda-tandanya-Nya kepada orang-orang bertaqwa."

Dalil yang ketiga Allah SWT menjelaskan bahwabarang siapa yang menyaksikan masuknya bulan ramadhan maka wajib semua muslimin berpuasa, dalam surat al-Baqarah ayat 185:

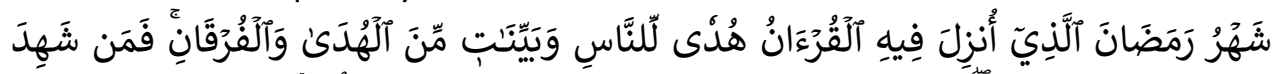

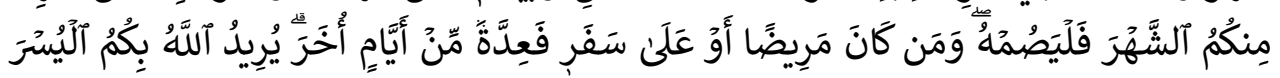

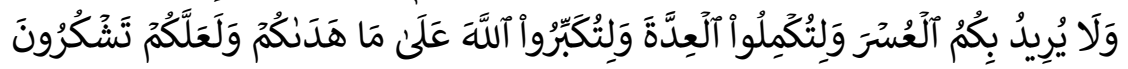

“(Beberapa hari yang ditentukan itu ialah) bulan Ramadhan, bulan yang di dalamnya diturunkan (permulaan) Al Quran sebagai petunjuk bagi manusia dan penjelasan-penjelasan mengenai petunjuk itu dan pembeda (antara yang hak dan yang bathil). karena itu, Barangsiapa di antara kamu hadir (di negeri tempat tinggalnya) di bulan itu, Maka hendaklah ia berpuasa pada bulan itu, dan Barangsiapa sakit atau dalam perjalanan (lalu ia berbuka), Maka (wajiblah baginya berpuasa), sebanyak hari yang ditinggalkannya itu, pada hari-hari yang lain. Allah menghendaki kemudahan bagimu, dan tidak menghendaki kesukaran bagimu. dan hendaklah kamu mencukupkan bilangannya dan hendaklah kamu mengagungkan Allah atas petunjuk-Nya yang diberikan kepadamu, supaya kamu bersyukur".

Ketiga dalil di atas dapat menunjukkan sebagai dasar hukum tentang hisab haqiqi tadqiqi sebagai podoman atau pedoman kita semua. 


\section{Hisab hakiki kontemporer}

Metode ini menggunakan hasil penelitian terakhir dan menggunakan matematika yang telah di kembangkan. Metodenya sama juga dengan metode hisab haqiqi tahqiqi hanya saja sistem koreksinya lebih teliti dan kompleks sesuai dengan kemajuan sains dan teknologi.rumus-rumusnya lebih disederhanakan sehingga untuk menghitungnya dapat digunakan kalkulator ketiga ini, seperti The New Comb, Astronomical Almanac, Islamic Calendar karya Mohammad Ilyas, dan mawaqit karya khafid (Bashori M. H., 2015). Di samping perbedaan metode hisab itu, masih banyak agi perbedaan intern dalam mazhab hisab. Di antaranya adalah perbedaan criteria penetapan awal bulam qamariah. Criteria yang banyak dipedomani oleh ahli hisab di Indonesia khususnya antara lain adalah:

a. Criteria ijtima', qabla al-grurub

b. Criteria ijtima' dan posisi hilal di atas ufuk. Oleh karena itu, komponen besar yang perlu dihitung dalam penentuan awal bulan qamariah adalah:

a. Saat terjadinya ijtima'

b. Saat matahari terbenam (sunset)

c. Ketinggian hilalpada saat matahari terbenam. Yang terakhior ini digunakan apabila criteria yang dipedomani adalah ijtima'dan posisi hilal di atas ufuk, sedangkan jika criteria yang dipedomani adalah ijtima' qabla al-ghurub, maka cukup menghitung saat terjadinya ijtima' dn saat matahari terbenam.

Hisab hakiki kontemporer merupakan sistem hisab yang paling akurat dalam perhitungan penentuan awal bulan hijriah, hal ini dikarenakan data bulan, matahari dan data lainnya dalam proses perhitungan selalu diperbaharui dalam setiap tahunnya dan proses perhitungan sudah menggunakan pemograman dan komputer. Rujukan yang termasuk dalam katagori hisab hakiki kontemporer adalah Jeen Meeus, New Comb, EW.Brouwn, Almanak Nautika, Ephemeris Hisab Rukyat, al-Falaqiyyah, Mawaqit, Astro info dan Starry Night Pro 5. 


\section{HISAB ‘URFI KHUMASI PENGIKUT HABIB SEUNAGAN NAGAN RAYA- ACEH.}

Dalam kajian ilmu falak, ada dikenal hisab 'urfi khumasi, yaitu sebuah sistem hisab yang mengacu kepada peredaran rata-rata bulan dalam setahun dengan siklus 8 tahun dan patokan siklus pada hari wukuf di Arafah. Hisab 'urfi khumasi pada dasarnya hanya diambil pada sepotong ucapan Ja'far Umar Shadiq yang ditulis oleh Syeikh Abdurrahman as-Syufuri as-Syafi'i dalam kitab Nuzhatul Majalis Wamuntakhabu an-Nafais. Nama lengkap beliau adalah Abdurrahman bin Abdissalam bin Abdurrahman bin Usman as-Syufuri wafat pada tahun $894 \mathrm{Hijriah}$ atau 1481 Masehi di Basrah. Kitab tersebut dalam kajianya berisi anjuran-anjuran yang berkaitan dengan aqidah, ibadah dan fikih, namun tidak ditemukan metode kusus yang spesifik membahas ilmu falak sebagaimana didapati dalam Sullam alNayyîrain, al-Khulâshah al-Wâfiyah dan kitab ilmu falak lainnya. Kitab tersebut hanya menerangkan penetapan awal Ramadhan berdasarkan 5 hari dari Ramadhan tahun sebelumnya (Ismail, 1 Syawal 10 Dzulhijjah),

Secara garis besar ada 3 karakteristik hisab 'urfi khumasi yang hampir sama dengan karakter hisab 'urfi lainnya:

1. Jumlah hari dalam satu tahun dihitung pada peredaran rata-rata bulan mengelilingi bumi dengan jumlah 30 hari pada tiap-tiap bulan ganjil dan 29 hari pada tiap-tiap bulan genap, sehingga jumlah hari bulan Ramadhan selalu 30 hari. Sistem ini terlihat sama antara sistem hisab 'urfi khumasi, hisab 'urfi Umar, hisab 'urfi Asapon dan hisab 'urfi Aboge.

2. Sistem hisab 'urfi pada umumnya ditetapkan siklus untuk kepentingan keakuratan dalam hal perhitungan. Hisab urfi khumasi memiliki siklus selama 8 tahun, hal ini sama dengan lama siklus hisab 'urfi Asapon dan hisab 'urfi Aboge, tetapi berbeda dengan siklus hisab 'urfi Umar dengan menetapkan jumlah siklus 30 tahun.

3. Hisab 'urfi khumasi memiliki patokan awal dalam proses awal perhitungan, hal ini sama halnya seperti hisab 'urfi Umar yang 
mengambil patokan untuk tanggal 1 bulan 1 tahun 1 saat sampai hijrah Rasulullah Saw di Madinah, hisab 'urfi Asapon yang mengambil patokan permulaan perhitungan pada tahun Alif jatuh pada hari Selasa Pon, hisab 'urfi Aboge dengan patokan awal perhitungan pada tahun Alif yang jatuh pada hari Rabu Wage. Hisab 'urfi khumasi mengambil patokan perhitungan pada hari Wukuf di 'Arafah hari 9 Zulhijah di Arab Saudi. Patokan ini dijadikan sandaran dalam menetapkan tanggal 10 Zulhijjah, 27 Rajab, 12 Rabiul Awal, 15 Syakban, 1 Ramadhan dan 1 Syawal. Kalau seandainya tahun ini Wukuf jatuh pada hari Selasa, maka bisa dipastikan tanggal 27 Rajab, 12 Rabiul Awal, 15 Syakban, dan 1 Syawal tahun depan jatuh juga pada hari Selasa, sedangkan untuk 1 Ramadhan dihitung mundur 3 hari dari hari Selasa (9 Zulhijah) sehingga 1 Ramadhan tahun depan jatuh pada hari Minggu. Setelah perhitungan ini selesai, untuk tahun berikutnya tinggal menghitung maju lima hari sampai 8 tahun kedepan dan pada tahun ke 8 dilakukan lagi proses perhitungan yang sama dengan merujuk pada hari wukuf di 'Arafah berikutnya (Ismail, 10 Dzulhijjah).

Hisab 'urfi khumasi pengikut Habib Seunagan Nagan Raya telah dimodifikasi dengan adat setempat, tidak murni mengacu kepada sistem hisab 'urfi yang telah ada dan tidak sepenuhnya mengadopsi sistem hisab 'urfi Abbas Kutakarang dalam kitab Tajul Muluk, dimana dalam mengawali puasa Ramadhan ada hari pantangan,yaitu hari Rabu, Jumat dan Minggu. Artinya, bila secara perhitungan hisab 'urfi khumasi awal Ramadhan jatuh pada hari Rabu, Jumat atau Minggu, maka adakalanya dilewatkan satu hari atau diundurkan satu hari. Pengunduran atau memajukan pada hari pantangan tergantung hasil musyawarah. Kalau dilihat lebih dalam, penentuan awal Ramadhan pengikut Habib Seunagan sepenuhnya mengacu kepada hasil musyawarah yang selalu diadakan pada tanggal 15 Syakban. Belum bisa dirumuskan secara detail metode penentuan awal Ramadhan 
yang sedang dipakai, karena tidak ada rujukan yang pasti dan metode yang tetap, lebih banyak modifikasi dari adat dan dominan keputusan hasil musyawarah.

Bila metode hisab 'urfi khumasi ini terus menurus dipakai tanpa ada siklus untuk memperbaharui perhitungan dan rujukan yang pasti, maka akan dijumpai perbedaan dalam mengawali puasa sampai 3 hari dengan penetapan pemerintah. Perbedaan ini tentunya sangat tidak sesuai dengan tuntunan syar'i. Dari data media yang mempulikasikan terhadap aktifitas mengawali puasa Ramadhan pengikut Habib Seunagan dapat dilihat dalam tabel di bawah ini.

Tabel. No. 1

Hasil penetapan awal Ramadhan pengikut Habib Seunagan dan pemerintah.

\begin{tabular}{|c|c|c|c|c|}
\hline No & Tahun & $\begin{array}{c}\text { Pengikut Habib } \\
\text { Seunagan }\end{array}$ & Pemerintah & Selisih hari \\
\hline 1 & $1433 \mathrm{H}$ & Kamis & Sabtu & 2 \\
\hline 2 & $1434 \mathrm{H}$ & Senin & Rabu & 2 \\
\hline 3 & $1435 \mathrm{H}$ & Jumat & Minggu & 2 \\
\hline 4 & $1436 \mathrm{H}$ & Selasa & Kamis & 2 \\
\hline 5 & $1437 \mathrm{H}$ & Sabtu & Senin & 2 \\
\hline 6 & $1438 \mathrm{H}$ & Kamis & Sabtu & 2 \\
\hline 7 & $1439 \mathrm{H}$ & Senin & Kamis & 3 \\
\hline 8 & $1440 \mathrm{H}$ & Sabtu & Senin & 2 \\
\hline
\end{tabular}

Dari tabel di atas dapat dilihat masih adanya pengaruh adat dalam penetapan awal Ramadhan bagi pengikut Habib Seunagan, pada tahun $1438 \mathrm{H}$ seharusnya secara hisab 'urfi khumasi jatuh pada hari Rabu, namun dimajukan pada hari Kamis, mengingat ada pantangan mengawali puasa pada hari Rabu. Pada tahun $1440 \mathrm{H}$ juga mengalami hal yang sama, seharusnya secara 'urfi khumasi awal Ramadhan jatuh pada hari Jumat, namun dimajukan menjadi hari 
Sabtu. Pantangan mengawali puasa pada hari Rabu dan Jumat masih dipatuhi dalam penentuan awal Ramadhan pengikut Habib Seunagan.

\section{SIMPULAN}

Pengikut Habib Seunagan Nagan Raya-Aceh dalam mengawali puasa Ramadhan menggunakan hisab 'urfi khumasi yang telah dimodifikasikan dengan pantangan adat, bukan menggunakan hisab hakiki taqribi dan bukan menggunakan rujukan kitab Tajul Muluk Syehk Abbas Kuta Karang. Sistem hisab 'urfi khumasi digunakan hanya sebagai perhitungan umum dalam menetukan awal puasa Ramadhan, sedangkan kepastian dalam mengawali puasa Ramadhan tetap mengacu kepada hasil musyawarah yang diadakan pada setiap tanggal 15 Syakban. Keputusan hasil musyawarah inilah yang menjadi pedoman dalam mengawali dan mengakhiri puasa disetiap datangnya bulan Ramadhan.

Bila melihat pada tuntunan ayat Alquran, hadis Nabi dan fatwa ulama, maka bisa dipastikan mengawali puasa Ramadhan dengan pedoman hisab 'urfi jauh menyimpang dari syari'at, karena mengawali puasa Ramadhan bukan dalam bulan Ramadhan. Secara syari'at kewajiban berpuasa harus mengacu kepada peredaran bulan yang hakiki atau secara hisab hakiki bukan secara 'urfi. Mengingat saat ini sudah mudahnya informasi sidang itsbat penetapan awal Ramadhan yang dilakukan oleh pemerintah, sudah sewajarnya seluruh masyarakat Indonesia mematuhi hasil sidang itsbat tersebut dan sudah saat nya pemerintah melarang praktik ibadah yang menyimpang jauh dari tuntunan syari'at ini.

\section{DAFTAR PUSTAKA}

Aini, Nur. 2018. "Perbandingan Sistem Penentuan Awal Bulan Kamariah Tarekat

Syatariah Peuleukung-Aceh Dan Tarekat Syatariah Ulakan-Padang." Undergraduate, UIN Walisongo Semarang.

Anugraha, Rinto. 2012. Mekanika Benda Langit. Yogyakarta: MIPA UGM. 
Faisal, Nurul Badriyah. 2018. "PENETAPAN AWAL BULAN DENGAN METODE ITTIHADUL MATHLA' DI INDONESIA." Al-Qadha 5, no. 1, 48-56.

Hambali, Slamet. 2013. IImu Falak III (Kajian kitab Al-khulasah al-Wafiyah bi Hasub al-Kalkulaturiyah). Semarang: eL-Wafa.

Isa, Teungku Mustafa Muhammad. 2016. Fiqih Falakiyah. Yogyakarta Deepublish. Ismail. 2018. "Melacak Metode Penentuan Awal Bulan Hijriah Pengikut Abu Peuleukung Nagan Raya (Analisis Penetapan 1 Ramadhan, 1 Syawal Dan 10 Zulhijah)." Al-Marshad: Jurnal Astronomi Islam Dan IImu-IImu Berkaitan 2, no. 2.

Khazin, Muhyiddin. 2005. Kamus Ilmu Falak. Yogyakarta: Buana Pustaka.

Marpaung, Wanti. 2018. "MAZHAB NEGARA: ALTERNATIF SOLUSI TERHADAP PERBEDAAN PENENTUAN AWAL BULAN QAMARIYAH DI INDONESIA." Jurisprudensi: Jurnal IImu Syariah, Perundang-Undangan, Ekonomi Islam 10, no. 2, 121-31.

Murtadho, Moh. 2008. Ilmu Falak Praktis. Yogyakarta: UIN malang Press.

Musonnif, Ahmad. 2019. "TIPOLOGI EPISTEMOLOGI HUKUM ISLAM (Analisis Metode Penetapan Awal Bulan Hijriyah Tokoh-Tokoh Agama Tulungagung)". Ahkam: Jurnal Hukum Islam. Vol. 7, No. 1, 1-26. https://doi.org/10.21274/ahkam.2019.7.1.1-26.

Pertiwi, Asih. 2017. "Metode Penentuan Awal Akhir Ramadan Menurut Tarekat Syattariyah Di Desa Peuleukung Kecamatan Seunagan Timur Kabupaten Nagan Raya Aceh." Undergraduate, UIN Walisongo.

Putri, Hasna Tuddar. 2013. "Pemikiran Syekh Abbas Kutakarang Tentang Hisab Penentuan Awal Bulan Hijriah." Masters, IAIN Walisongo.

Qulub, Siti Tatmainul. 2015. "Telaah Kritis Putusan Sidang Itsbat Penetapan Awal Bulan Qamariyah Di Indonesia Dalam Perspektif Ushul Fikih." AL-AHKAM 25, 109-32. 
Rizky, Cut Rahma. 2017. "Patronase Masyarakat Peuleukung (Nagan Raya) Pengikut Abu Habib Muda Seunagan Dalam Menentukan 1 Ramadan." Undergraduate. UIN Walisongo.

Tim Penyusun Kemenag RI. 2019. Ephemeris (ephemeris) Hisab Rukyat 2019. Dirjen Bimas Islam Depag RI.

Wahidi, Ahmad. 2012. "MENYATUKAN PENETAPAN 1 RAMADLAN, SYAWAL DAN DZULHIJJAH DI INDONESIA." JURISDICTIE 0, no. 0.

Yusuf, Muchtar. 2010. Ilmu Hisab dan Rukyah. Banda Aceh: Al-Wasliyah University Press. 